\title{
DIFFERENCES IN NUTRITIONAL STATUS OF INFANTS AGED 4-6 MONTHS WHO WERE EXCLUSIVELY BREASTFED AND THOSE WERE GIVEN NONEXCLUSIVE BREASTFEEDING : LITERATURE REVIEW
}

\author{
Frisna Dwika Maheni ${ }^{1}$, Abdiana $^{2}$, Rafika Oktova ${ }^{3}$ \\ ${ }^{1}$ Bachelor of Midwifery Program, Faculty of Medicine, Universitas Andalas, Padang, Indonesia \\ ${ }^{2}$ Lecturer in Departement of Public Health, Faculty of Medicine, Universitas Andalas, Padang, Indonesia \\ ${ }^{3}$ Lecturer of Midwifery Program, Faculty of Medicine, Universitas Andalas, Padang, Indonesia
}

\section{INFORMASI ARTIKEL:}

\section{Riwayat Artikel:}

Tanggal diterima: Maret 2021

Tanggal di revisi: Maret 2021

Tanggal di Publikasi: April 2021

Key Word: Infant Feeding Practices, Infant Nutritional Status, Early Complementary Feeding, Exclusive Breastfeeding, Baby Weigh

\section{A B S T R A C T}

World Health Organization (WHO) recommends that babies remain given exclusive breast milk for the first six months of a baby's life. However, there were some obstacles that cause the mother to be unable to give exclusive breast milk to her baby. By the time the baby becoming 4 to 6 months, the opportunity to provided exclusive breast milk is reduced because of many factor such as working mother can be an obstacle to providing exclusive breast milk. Often for mothers prefer to provide formula milk or complementary food for their babies to make it simply.This literature review aims to determine the differences in nutritional status of infants who were exclusively breastfed and those who were not exclusively breastfed at the age of 4 to 6 months. This literature review is semi-quantitative using the narrative review method. The search for articles accessed from the PubMed, Google Scholar, and Science Direct database found 40 articles that met the criteria. There were differences in the nutritional status of infants who were exclusively breastfed and those who were given non-exclusive breastfeeding. Babies who were exclusively breastfed at the age of 4 to 6 months had a better nutritional status than babies who were given nonexclusive breastfeeding 


\section{INTRODUCTION}

Breastmilk is the main food for babies from first 6 month of life. At first, the baby cannot consume other additional food unless breastfeeding. In breast milk contains the most complete nutrition for babies. Breast milk is the first natural food for babies. World Health Organization (WHO), recommends that babies continue to be exclusively breastfed for the first six months of a baby's life. In exclusive breastfeeding, babies who were breastfed only until they were 6 months old, except for drugs and minerals. This is based on the evidence that breast milk has positive benefits for the health of infants, including as the best source of nutrition for growth and protecting babies from life-threatening diseases such as ARI and diarrhea.[1,2]

The advantages of exclusive breastfeeding include breastfeeding is always available for every baby needs, it costs nothing, can be given directly when needed, and the baby can adjust the amount of milk he needs at each feeding time. The ingredients in breast milk were exclusive, cannot be fully replicated by formula milk and other food additives and provide many benefits for both mother and baby. Despite the many benefits of breastfeeding, WHO estimates that only $40 \%$ of all babies in the world were exclusively breastfed within the first 6 months of life.[3]

The quality and quantity of nutrients given to children during infancy were essential for supporting optimal growth and development. Measuring and weighing children at each stage of their growth is very important to help identify nutritional status. Measurement of nutritional status is based on World Health Organization (WHO) standards which have been established in the Minister of Health Decree No. 1995 / Menkes / SK / XII / 2010 concerning Anthropometric Standards for Assessing Children's Nutritional Status. Nutritional status can affect the body's response to disease and treatment. Good nutrition or optimal nutrition, is important in

*Korespondensi: E-mail :yuniarsetya2@gmail.com improving health, preventing disease, and restoring health after trauma or illness. Meanwhile, malnutrition or malnutrition is a state of inadequate or excessive nutritional intake.[4,5,6]

There were several obstacles that cause mothers to not be able to provide exclusive breastfeeding to their babies, namely the shape of the mother's breasts, perceptions of insufficient breast milk, health problems for mothers or babies, lack of knowledge about the importance of breastfeeding, incessant promotion of formula milk to sociocultural influences in society. Working mothers also support low levels of breastfeeding for babies. When the baby is 4 to 6 months old, the opportunity to provide exclusive breastfeeding is reduced because work can become an obstacle to exclusive breastfeeding. It is not uncommon for mothers to choose to give formula milk or complementary foods to their babies early to make it more practical.[7,8,9]

People who do not have knowledge about the importance of exclusive breastfeeding often provide additional food other than breast milk when the baby is <6 months old. Some cultures that have been passed down from generation to generation were still encountered today, namely the provision of tajin water (boiled rice water), bananas, sugar water, tea, honey, porridge and others. The first solid foods introduced to babies were rice porridge, baby cereal, fruit and vegetables. Baby cereal is a solid food that is most often introduced before six months of age. Infants under 6 months also have an immature digestive system. If you force your baby to eat at this age, your baby's digestion has to work extra hard. Incoming food cannot be digested properly because digestion is not ready. As a result, digestive disorders such as diarrhea can occur. $[10,11,8]$

The mean weight gain in infants was higher at 1-3 months of age, but at this age there was no significant difference between the exclusive and non-exclusive groups. Meanwhile, at the age of 4-6 months, there is a trend that the average weight growth of babies who were 
exclusively breastfed is higher than those who were not exclusively breastfed. This means that the average weight gain in the first 3 months after birth is not much different, while starting at 4 months of age it is higher in infants who were exclusively breastfed.[9].

Infants aged 4-6 months have a tendency that non exclusively breastfed babies have a higher risk greater the incidence of abnormal nutritional status compared to exclusive breastfeeding. The occurrence of nutritional problems in infants is caused partly by the fact that breast milk is largely replaced by formula milk in amounts and methods that were not suitable for the baby's needs. Early detection of cases of malnutrition and malnutrition can be done through weighing children under five. By routinely weighing toddlers, toddlers' growth can be monitored intensively. This is intended if the child's weight does not

\section{RESULT AND DISCUSSION}

Weight gain for infants aged 4-6 months The obesity rate in infants was lower in the exclusive breastfeeding group $(8.6 \%)$ than in the other two groups $(8.8 \%$ for formula feeding only and partially breastfeeding groups). The percentage of overweight infants who were exclusively breastfed $(9.4 \%)$ was lower than that of the partially breastfed group $(10.6 \%)$ or the formula-fed group (10.8\%).[14] Incidence of being overweight lower body in the exclusive breastfeeding group. The practice of exclusive breastfeeding has an effect on infant weight at 4 to 6 months of age and has no significant effect thereafter. If EBF is stopped for $0-2$ months, the 2-4 months likelihood of an infant becoming thin is 2,16 times and 2,01 times higher, respectively, than an infant who continues to be exclusively breastfed.[15] At 4 to 6 months of age, exclusively breastfed babies gained less weight than formula-fed babies. It has been shown that formula-fed babies receive excess protein and increased body fat compared to exclusively breastfed babies. When examining overweight and obese children separately, those who were fed only formula milk were more likely to be obese than their breast-fed increase. or if disease is found, efforts to recover and prevent it can be immediately carried out so that it does not become malnutrition or malnutrition. The sooner it is found, cases of malnutrition or malnutrition, the faster it will be handled.[12,13] The aim of this literature review is to determine the differences in nutritional status of infants who were exclusively breastfed and those who were not exclusively breastfed at the age of 4 to 6 month.

\section{METHOD}

This literature review is semi-quantitative using the narrative review method. In this literature review, the authors searched data through accessible journal websites such as Pubmed, Google Scholar, and Science Direct. Searching for articles from the database found 40 articles that met the criteria. peers. Those who were given combination feeding for $<6$ months compared to those who were given only breast milk were more likely to be overweight.[17,18]

Non-exclusive breastfeeding is associated with the risk of being overweight in infants 4-6 months. Early stopping breastfeeding is associated with an increased risk of being overweight. Proper feeding practices can promote healthy eating behavior in babies and children and encourage proper weight gain. On the other hand, inappropriate feeding practices tend to result in inappropriate weight gain. $[19,20]$

Exclusive breastfeeding (EBF) during the first 6 months of life is associated with a lower incidence of diarrhea and respiratory disease in infants, especially in developing countries. Lower levels of breast milk consumption or contaminated food that causes infection can cause the baby to be malnourished and / or have poor growth. A study also found that young infants under the age of six months were not physiologically ready to receive complementary foods because their nervous, gastrointestinal system and kidneys were still not developing optimally.[21,22] 
Frequency distribution of infants aged 4-6 months who were exclusively breastfed and babies who were given non-exclusive breastfeeding

Table 4.1 Resume frequency distribution of infants aged 4-6 months months who were exclusively breastfed and babies who were given non-exclusive breastfeeding $[14,24,52]$

\begin{tabular}{llcc}
\hline No & $\begin{array}{c}\text { Researcher } \\
\text { (year) }\end{array}$ & \multicolumn{2}{c}{ Feeding Practice } \\
\cline { 3 - 4 } & & $\begin{array}{c}\text { Exclusive } \\
\text { breastfeeding }\end{array}$ & $\begin{array}{c}\text { Non exclusive } \\
\text { breastfeeding }\end{array}$ \\
\hline 1 & $\begin{array}{l}\text { Park } \\
(2018)\end{array}$ & $46 \%$ & $54 \%$ \\
2 & $\begin{array}{l}\text { Kurniawan } \\
(2018)\end{array}$ & $75 \%$ & $25 \%$ \\
3 & $\begin{array}{l}\text { Purba } \\
(2018)\end{array}$ & $30,2 \%$ & $69,8 \%$ \\
\hline
\end{tabular}

As many as $20 \%$ to $40 \%$ of infants were introduced to solid food before 4 months of age, with details of $16.3 \%$ of babies introduced to complementary foods before 4 months and $54.6 \%$ of babies introduced to complementary foods before 6 months recommended by WHO.[23] Breastfeeding nonexclusive can be in the form of partial breastfeeding, early solids and infant formula. It was found that $75 \%$ of babies aged 4-6 months were exclusively breastfed. Meanwhile, $11 \%$ of babies were given breast milk and formula milk, $8 \%$ of babies were given breast milk and early solids, and $6 \%$ of babies were given formula milk and early solids.[24]

About $27 \%$ of infants have received complementary foods at 4 months of age and the figure increases to $90.7 \%$ within 6 months. Fruit juices and vegetable juices were the earliest foods introduced to babies, followed by baby cereals. Most mothers have introduced solid foods to their babies before 6 months of age. Other foods given to babies also vary, consisting of several types of foods with the most common foods being fruits and natural juices, cereals, baby biscuits and vegetables. The findings from the Infants Feeding and Toddlers Study found that parents of infants aged 4 to 6 months reported that $65,8 \%$ consumed whole grain products (rice, cereals), 39,9\% vegetables, $41,9 \%$ fruit, and $14,2 \%$ meat or other. [25] Mothers who return to work when the baby is less than 6 months old, the mother tends to give formula milk. Formula milk is another type of food that is commonly consumed, indicating that babies who were partially breastfed were more likely to received formula milk other than breast milk.[26,27]

Breast milk has a very important role in the growth and development of babies. It is the best source of nutrition for babies, as it is a cost-effective and appropriate method of feeding babies and minimizing the risk of atopic disease. Breast milk also contains many nutrients that prevent malnutrition during infancy. Breastfeeding usually results in better nutritional status for all anthropometric indices. [28] Breast milk is not only a source of the essential nutrients every child needs to thrive; it is also economical and safe. The used of infant formula exclusively for feeding infants can lead to growth problems, micronutrient malnutrition and serious diarrhea if formula milk is not prepared properly.[29].

Frequency distribution of nutritional status of infants aged 4-6 months who were exclusively breastfed and infants who were given nonexclusive breastfeeding

Table 4.2 Resume of frequency distribution of nutritional status of infants aged 4-6 months who were exclusively breastfed and infants who were given non-exclusive breastfeeding [39,52]

\begin{tabular}{lllccc}
\hline No & $\begin{array}{c}\text { Researcher } \\
\text { (year) }\end{array}$ & \multicolumn{4}{c}{ Nutritional Status } \\
\cline { 3 - 6 } & & \multicolumn{2}{c}{$\begin{array}{c}\text { Exclusive } \\
\text { Breastfeeding }\end{array}$} & \multicolumn{2}{c}{$\begin{array}{c}\text { Non Exclusive } \\
\text { Breastfeeding }\end{array}$} \\
\cline { 3 - 6 } & & Good & Bad & Good & Bad \\
\hline 1 & $\begin{array}{l}\text { Karuniawati } \\
\text { (2016) }\end{array}$ & $62,5 \%$ & $37,5 \%$ & $50 \%$ & $50 \%$ \\
2 & $\begin{array}{l}\text { Purba } \\
(2018)\end{array}$ & $93,8 \%$ & $6,2 \%$ & $58,8 \%$ & $41,2 \%$ \\
\hline
\end{tabular}

The nutritional status of infants has a significant relationship in exclusive breastfeeding. This may be due to the fact that body weight for age is an indicator of acute 
malnutrition.[30] There is a relationship between increasing the nutritional status of infants and optimal infant feeding practices by the mother. Delayed initiation of early breastfeeding, deficiency of colostrum and inappropriate complementary feeding were risk factors affecting malnutrition in infancy. Severe malnutrition was significantly higher in infants whose weaning was delayed.[31] Maternal education about the benefits of colostrum administration and proper feeding methods for newborns should be well socialized.[32]

Late introduction of complementary foods was associated with a higher prevalence of underweight among children who discontinued EBF at 4-6 months of age, whereas early introduction of solids ( $<6$ months) was associated with a prevalence of overweight / obesity in children who discontinue exclusive breastfeeding earlier than 4 months of age.[33] Infants who were introduced to formula and solid foods earlier have been found to consume more foods high in sugar, which can increase consumption of excess calories and lead to rapid weight gain.[34]

Malnutrition during the first 2 years of life is one of the determinants of stunting in childhood and noncommunicable diseases in adulthood. Inadequate nutrition during the first 1000 days of life can hinder physical and cognitive development and increase the risk of child death. Adequate nutrition during this critical time is essential for healthy growth and development.[35,36]

The most common reason for stopping exclusive breastfeeding is to resume work earlier after delivery. In working mothers, exclusive breastfeeding tends to be lower than mothers who do not work. Breastfeeding is replaced with formula milk or early complementary food. Factors such as the educational status of the mother and her husband, the husband's occupation, the place of delivery, the sex of the newborn, the frequency of breastfeeding per day, the practice of expressing and storing breast milk before leaving for work and resting during working hours were statistically proven by the practice of exclusive breastfeeding. The heavy workload of mothers means that they do not have enough time to breastfeed and care for their babies because of the large amount of household chores and work outside the home. This is of particular concern for women between 4 and 6 months postpartum. $[37,38,46]$

\section{Differences in nutritional status of infants aged 4-6 months who were exclusively breastfed and those who were given non- exclusive breastfeeding.}

Babies who were given exclusive breastfeeding have a better nutritional status than those who were not exclusively breastfed. Malnutrition status was more prevalent in the group of infants who were not exclusively breastfed.[39] The group that was given exclusive breastfeeding had better nutritional status than the group that was given nonexclusive breastfeeding. The incidence of overnutrition was lower in the exclusive breastfeeding group. The percentage of overweight in the exclusive breastfeeding group was lower than that in the partial or exclusive breastfeeding group. Babies who were exclusively breastfed at 4-6 months of age have a $22 \%$ lower risk of being overweight and that babies who were partially breastfed have a $4 \%$ lower risk of being overweight than babies who were fed formula milk.[14,24,40]

The duration of breastfeeding is known to be an important factor in reducing the risk of obesity in infants. Adherence to recommended breastfeeding practices is associated with a lower risk of being overweight or obese in infants and children. The risk of being overweight tends to be lower in children whose breast milk criteria were met. The timing of the introduction of complementary foods also affects the nutritional status of the baby. Providing complementary foods too early or too late will increase the risk of malnutrition.[41,44,45]

Breastfeeding patterns also affect the nutritional status of the baby. Normal nutritional status tends to be more common in 
subjects with good breastfeeding patterns, about $94,7 \%$ compared to $80 \%$ in the group with poor breastfeeding patterns. Undernutrition and malnutrition were also more likely to be found in babies with poor breastfeeding patterns. A higher normal nutritional status in infants with a good breastfeeding pattern is possible because a good breastfeeding pattern ensures that breast milk can be obtained by the baby more effectively. Breast milk really supports the growth and development of babies because in addition to nutritional content, breast milk also contains hormones and growth factors.[41]

During this crucial growing period of 4 to 6 months, more energy is needed. However, when complementary foods were introduced at that time, it is important to note that the quality and frequency of supplementary feeding will have a negative impact on breast milk intake. Malnutrition at this age affects health later in life. It is scientifically proven that improper feeding practices can have a major impact on growth and development including the survival of infants and young children.[42]

A child's diet affects their nutritional status, which determines their potential for growth and development. Good breastfeeding practices can provide the baby with adequate nutrition and immunity from a large number of infections and allergies. Severe malnutrition is significantly higher in children where weaning is delayed.[43,44] Interventions to increase dietary diversity, breastfeeding practices, and start complementary foods on time were important to reduce malnutrition. [45]

Support for breastfeeding by the spouse or father of the child was identified as the main source of support both financially and morally in infant feeding practices. Other sources of support that were identified were relatives such as grandparents, grandmothers and aunts. Some mothers feel that someone with experience in parenting can provide valuable advice even if some of it is not true. They show that midwives play an important source of support because they were very knowledgeable and share knowledge during antenatal and under-five clinic visits.[46,47]

Parent's perceptual problems about their baby's appetite were the most commonly reported reasons for switching to infant formula. This is followed by the advice you receive from health professionals. The influence of health workers plays a major role in the practice of formula feeding, especially observed at 2 months of age.[48] Support from families and health workers is needed to achieve the success of exclusive breastfeeding until the age of 6 months. $[49,46]$

Additional support for parents who feed their babies with milk formula is required. Parents access information from a number of nonscientific sources and they express a need for advice from health practitioners. Health professionals and policies around the use of infant formula should included information that formula milk can be provided to parents using formula in a way that does not interfere with the promotion of breastfeeding. [50,51]

The success of exclusive breastfeeding is also influenced by early breastfeeding for babies. Early initiation of breastfeeding also determines the success of exclusive breastfeeding. Early initiation of breastfeeding is very important not only for babies but also mothers.[52] Optimal exclusive breastfeeding until the age of 6 months for infants has a good impact on nutritional status compared to babies who were started on complementary foods at the age of 4 months. Poor infant feeding practices were found in many mothers who have never received breastfeeding counseling. Several studies have shown that counseling helps improve feeding practices. To reach the dietary standards recommended by the WHO requires a level of behavior change at the family level, requires an innovative approach to counseling is very important. [53]

\section{CONCLUSION}

1. The weight gain of infants who were exclusively breastfed tends to be optimal than in infants who were given non-exclusive breastfeeding. This is 
because exclusive breastfeeding can meet the nutrition needs of babies up to 6 months of age. Meanwhile, babies who were given nonexclusive breastfeeding were at risk of experiencing malnutrition due to improper feeding.

2. Non-exclusive breastfeeding includes early complementary feeding (MPASI) and formula milk. There were many factors that influence this feeding practice. The factors that had the most influence were low knowledge about exclusive breastfeeding and mothers returning to work. The period of leave from work that ends after 3 months postpartum makes the mother choose to provide non-exclusive breastfeeding by providing formula milk as a substitute for or supporting the needs of the baby's milk.

3. The nutritional status of infants at 4-6 months of age is very dependent on the type of food the baby had consume. Most mothers begin to introduce solid foods and complementary foods to breast milk from the age of 4 months. Inappropriate feeding practices can result in malnutrition or overnutrition in infants and increase the risk of stunting and obesity in childhood.

4. There is a difference between the nutritional status of the baby and the optimal feeding practices for babies by the mother. Babies who were exclusively breastfed at the age of 4 to 6 months had a better nutritional status than babies who were given nonexclusive breastfeeding.

\section{AKNOWLEDGEMENT}

Thank you to the Midwifery Program and the Faculty of Medicine, Andalas University, lecturers and examiners, thesis / literature review coordinator, and academic staff who have supported the writing of this literature review.

\section{REFERENCE}

1. WHO (2018). Breastfeeding. World Health Organization, dari http://www.who.int/nutrition/topics/ex clusive br eastfeeding/en/ Diakses 12 November 2019

2. Kementerian Kesehatan RI. Infodatin : Menyusui sebagai dasar kehidupan. Jakarta: Kemenkes RI; 2018. ISSN 2442-7659

3. Pollard, M. ASI asuhan berbasis bukti. Alih bahasa, E. Elly wiriawan. Jakarta : EGC; 2015.

4. Bartleman, J. Infant and child nutrition. Journal pediatric nutrition. medicine. Elsevier. 2019; Vol 47(3).

5. Supariasa, I.D.N., B. Bakri. dan I. Fajar. Penilaian Status Gizi. Jakarta: EGC; 2012.

6. Dwijayanthi, L. Ilmu gizi menjadi sangat mudah edisi 2. Jakarta: EGC; 2011.

7. Sitepoe, M. ASI eksklusif : arti penting bagi kehidupan. Jakarta: Indeks; 2013.

8. Khasanah, N. ASI atau Susu Formula Ya?. Jakarta: Flashbook; 2011.

9. Andriany E, Ahmad A, Yuniwati C. Perbedaan pertumbuhan berat badan bayi ASI ekslusif dan non eksklusif di wilayah kerja Puskesmas Peukan bada Kabupaten Aceh besar. Idea nursing journal. 2013; vol. IV no. 2.

10. Heryanto, E. Faktor-Faktor yang berhubungan dengan Pemberian Makanan Pendamping ASI Dini. Aisyah: jurnal ilmu kesehatan 2 (2). 2017; $141-152$.

11. Chuan Y, Colin W. Binns, and Andy H. Lee. The Early Introduction of Complementary (Solid) Foods: A Prospective Cohort Study of Infants in Chengdu, China. Nutrients. 2019; 11, 760; MDPI 
12. Ginanti, N. A. Hubungan praktik pemberian air susu ibu (ASI) dengan status gizi bayi (usia 0-6 bulan) di wilayah kerjaPuskesmas gayamsari kota semarang. Jurnal kesehatan masyarakat (ejournal) FKM UNDIP. 2015; Volume 3 No 3.

13. Kementerian Kesehatan RI . Profil kesehatan Indonesia tahun 2018. Jakarta: Kemenkes RI; 2019.

14. Park SJ, Lee HJ. Exclusive breastfeeding and partial breastfeeding reduce the risk of overweight in childhood: A nationwide longitudinal study in Korea. Obes Res Clin Pract [Internet]. 2018;12(2):222-8. Available from: http://dx.doi.org/10.1016/j.orcp.2018.0 $\underline{1.001}$

15. Khan MN, Islam MM. Effect of exclusive breastfeeding on selected adverse health and nutritional outcomes: A nationally representative study. BMC Public Health. 2017;17(1):1-7.

16. Nigatu D, Azage M, Motbainor A. Effect of exclusive breastfeeding cessation time on childhood morbidity and adverse nutritional outcomes in Ethiopia: Analysis of the demographic and health surveys. PLoS One. 2019;14(10):1-12.

17. Haschke F, Grathwohl D, Detzel P, Steenhout P, Wagemans N, Erdmann P. Postnatal High Protein Intake Can Contribute to Accelerated Weight Gain of Infants and Increased Obesity Risk. Nestle Nutr Inst Workshop Ser. 2016;85:101-9. 1

18. Rossiter MD, Colapinto CK, Khan MKA, McIsaac JLD, Williams PL, Kirk SFL, et al. Breast, Formula and Combination Feeding in Relation to Childhood Obesity in Nova Scotia, Canada. Matern Child Health J. 2015;
19. (9):2048-56. 19.Forbes JD, Azad MB, Vehling L, Tun HM, Konya TB, Guttman DS, et al. Association of exposure to formula in the hospital and subsequent infant feeding practices with gut microbiota and risk of overweight in the first year of life. JAMA Pediatr. 2018;172(7):1-11.

20. Ma JQ, Zhou LL, Hu YQ, Liu SS, Sheng XY. Association between feeding practices and weight status in young children. BMC Pediatr [Internet].2015;15(1):1-10. Available from:

http://dx.doi.org/10.1186/s12887-015$\underline{0418-4}$

21. Ashok A, H. SJ, K. MT. A comparative study of impact of breastfeeding practices on the nutritional status of the infants among the working and non-working women. Int J Contemp Pediatr. 2018;5(5):1759.

22. Alzaheb RA. Factors associated with the early introduction of complementary feeding in Saudi Arabia. Int $\mathbf{J}$ Environ Res Public Health. 2016;13(7).

23. Barrera CM, Hamner HC, Perrine CG, Scanlon KS. Timing of Introduction of Complementary Foods to US Infants, National Health and Nutrition Examination Survey 2009-2014. J Acad Nutr Diet [Internet].2018;118(3):464-70. Available from: https://doi.org/10.1016/j.jand.2017.10. $\underline{020}$

24. Kurniawan J, Anggraini A, Julia M. Infant feeding practice on growth velocity in 4 to 6 - month-olds. paediatr indones. 2018; p-issn 0030-9311; eissn 2338-476x; vol.58, no.1P. 36- 41 ; doi:http://dx.doi.org/10.14238/pi58.1.2 018.36-41

25. Borresen EC, Guajardo MC, Zambrana LE, Perez J, Perez C, Stallones L, et al. Association between Infant Feeding 
Practices and Nutritional Status in Healthy Nicaraguan Infants. 2016;4-9.

26. Boundy EON, Fisher Boyd A, Hamner HC, Belay B, Liebhart JL, Lindros J, et al. US Pediatrician Practices on Early Nutrition, Feeding, and Growth. J Nutr Educ Behav [Internet]. 2020;52(1):318. Available from: https://doi.org/10.1016/j.jneb.2019.10. $\underline{006}$

27. Helle C, Hillesund ER, Overby NC. Timing of complementary feeding and associations with maternal and infant characteristics: A Norwegian crosssectional study. PLoS One. 2018;13(6):1- 20.

28. Safri M, Putra AR, Mulya VC. Nutritional status of infants with cow's milk allergy who consume breast milk vs. Hypoallergenic formula. paediatr indones. 2016; p-issn 0030-9311; eissn 2338- 476x; vol.56 no.5(2016) p.311-4; doi: 10.14238/pi56.5.2016.311-4.

29. Odton P. Breastfeeding and Nutritional Status among Children in Thailand. 2018;1(1):1-12.

30. Anoshirike C, O OT, C OP, Ogbu C, Asinobi C, Ofoezie EI. Exclusive Breastfeeding Practice and Nutritional Status of Infants Attending University of Nigeria Teaching Hospital Enugu, Nigeria. Int J Innov Stud Sci Eng Technol [Internet]. 2017;4863(2):2455-4863. Available from: www.ijisset.org

31. Meshram II, Mallikharjun Rao K, Balakrishna N, Harikumar R, Arlappa $\mathrm{N}$, Sreeramakrishna K, et al. Infant and young child feeding practices, sociodemographic factors and their association with nutritional status of children aged $<3$ years in India: Findings of the National Nutrition Monitoring Bureau survey, 2011-2012. Public Health Nutr. 2019;22(1):10414.
32. Wubante AA. Determinants of infant nutritional status in Dabat district, North Gondar, Ethiopia: A case control study. PLoS One. 2017;12(3):1-9.

33. Papoutsou S, Savva SC, Hunsberger M, Jilani H, Michels N, Ahrens W, et al. Timing of solid food introduction and association with later childhood overweight and obesity: The IDEFICS study. Matern Child Nutr. 2018;14(1):1-8.

34. Doub QAE, Moding KJ, Stifter CA. Infant and maternal predictors of early life feeding decisions. The timing of solid food introduction. Appetite [Internet].2015;

Availablefrom:http://dx.doi.org/10.101 6/j.appet.201 5.05.028

35. Syeda B, Agho K, Wilson L, Maheshwari GK, Raza MQ. Relationship between breastfeeding duration and undernutrition conditions among children aged 0-3 Years in Pakistan. Int $\mathrm{J}$ Pediatr Adolesc Med [Internet]. 2020;(xxxx):1-8. Available from:

https://doi.org/10.1016/j.ijpam.2020.01 $\underline{.006}$

36. Walters $\mathrm{CN}$, Rakotomanana $\mathrm{H}$, Komakech JJ, Stoecker BJ. Maternal determinants of optimal breastfeeding and complementary feeding and their association with child undernutrition in Malawi (2015-2016). BMC Public Health. 2019;19(1):1-12.

37. Ahishakiye J, Bouwman L, Brouwer ID, Vaandrager L, Koelen M. Prenatal infant feeding intentions and actual feeding practices during the first six months postpartum in rural Rwanda: A qualitative, longitudinal cohort study. Int Breastfeed J. 2020;15(1):1-14.

38. Chhetri S, Rao AP, Guddattu V. Factors affecting exclusive breastfeeding (EBF) among working mothers in Udupi taluk, Karnataka. Clin Epidemiol Glob Heal [Internet]. 
2018;6(4):216- 9. Available from: https://doi.org/10.1016/i.cegh.2018.06. $\underline{008}$

39. Karuniawati MC, Dasuki MS, Candrasari A. Perbedaan status gizi bayi berumur 4-6 bulan pada pemberian ASI eksklusif dengan ASI non eksklusif. Biomedika. 2016; volume 8 nomor 1

40. Campbell RK, Aguayo VM, Kang Y, Dzed L, Joshi V, Waid J, et al. Infant and young child feeding practices and nutritional status in Bhutan. Matern Child Nutr. 2018;14(May 2017):1-6.

41. Christy EM,1 Sukmaniah S, Sekartini R. Breastfeeding pattern and its association with nutritional status and salivary secretory immunoglobulin a level in 3-6 months old infants. World nutr.j. 2017; Eissn 2580-7013; doi:10.25220/wnj/v01.i2.0009

42. Halakhe A. Determinants of Early Complementary Feeding Practices among Children below 6 Months Old in Kisii Level 6 Hospital in Kisii County. Acta Sci Nutr Heal. 2019;3(8):84-94.

43. Urteaga N, San Miguel JL, Aguilar AM, Muñoz M, Slater C. Nutritional status and human milk intake of exclusively breast-fed infants at high altitude in la Paz, Bolivia. Br J Nutr. 2018;120(2):158-63.

44. Gadappa SM, Behera MK. Nutritional Status and Feeding Practices in Relation to IYCN Policy Among Children under 2 Years of Age in Tertiary Cwere Centre. Orig Res. 2016;3(6):1650-2.

45. Fekadu Y, Mesfin A, Haile D, Stoecker BJ. Factors associated with nutritional status of infants and young children in Somali Region, Ethiopia: A crosssectional study Global health. BMC Public Health [Internet]. 2015;15(1):19. Available from: http://dx.doi.org/10.1186/s12889-015$\underline{2190-7}$

46. Alianmoghaddam N, Phibbs S, Benn C. Reasons for Stopping Exclusive Breastfeeding Between Three and Six Months: A Qualitative Study. J Pediatr Nurs [Internet]. 2018;39:37-43. Available from: https://doi.org/10.1016/j.pedn.2018.01. $\underline{007}$

47. Bwalya KM, Mukonka V, Kankasa C, Masaninga F, Babaniyi O, Siziya S. Infants and young children feeding practices and nutritional status in two districts of Zambia. Int Breastfeed J. 2015;10(1):1-8.

48. Smith HA, Hourihane JOB, Kenny LC, Kiely M, Leahy-Warren P, Murray DM. Infant formula feeding practices in a prospective population based study. BMC Pediatr [Internet]. 2016;16(1):1-7. Available from: http://dx.doi.org/10.1186/s12887-016$\underline{0754-\mathrm{Z}}$

49. Das A, Mala GS, Singh RS, Majumdar A, Chatterjee R, Chaudhuri I, et al. Prelacteal feeding practice and maintenance of exclusive breast feeding in Bihar, India - Identifying key demographic sections for childhood nutrition interventions: A cross-sectional study. Gates Open Res. 2019;3:1-13.

50. Garcia AL, Looby S, McLean-Guthrie K, Parrett A. An exploration of complementary feeding practices, information needs and sources. Int $\mathbf{J}$ Environ Res Public Health. 2019;16(22).

51. Appleton J, Laws R, Russell CG, Fowler C, Campbell KJ, DenneyWilson E. Infant formula feeding practices and the role of advice and support: An exploratory qualitative study. BMC Pediatr. 2018;18(1) :1-11. 
52. Purba RB, Rumagit FA, dan Taher R. Status gizi bayi $4-6$ bulan yang mendapatkan ASI eksklusif dan ASI non eksklusif di Puskesmas Kolongan Kecamatan Kalawat Kabupaten minahasa utara. Gizido. 2018; Volume 10 no. 1

53. Gupta S, Agarwal R, Aggarwal KC, Chellani H, Duggal A, Arya S, et al. Complementary feeding at 4 versus 6 months of age for preterm infants born at less than 34 weeks of gestation: a randomised, open-label, multicentre trial. Lancet Glob Heal. 2017;5(5):e501-11. 